\title{
Kartografia historyczna między humanistyczną metodą badawczą a przyrodniczą metodą prezentacji
}

Badania humanistyczne odwołują się do niejednoznacznych i niepełnych źródeł, a w konsekwencji ich wynikiem są dane niekompletne i nacechowane różnym, zwykle niemierzalnym stopniem prawdopodobieństwa. Przedstawienie kartograficzne wymaga natomiast kompletności, gdyż każdy sposób zapełnienia powierzchni mapy jest konkretną informacją, i jednoznaczności, ponieważ nie da się przedstawić na mapie drogi rozumowania wiodącej od źródła do rezultatu dociekań. $Z$ tą strukturalną sprzecznością musi zmierzyć się każdy kartograf historyczny.

Sympozjum, które odbyło się 17 września 2014 r. w ramach XIX Powszechnego Zjazdu Historyków Polskich w Szczecinie, miało na celu wymianę doświadczeń w tej dziedzinie. Każdy z referatów został poświęcony sposobom rozwiązania problemu w poszczególnych dziedzinach kartografii historycznej i zarazem na przykładzie konkretnego, realizowanego aktualnie projektu. Chodziło o to, żeby prezentowane tezy wypływały z praktyki badawczej, podsumowywały faktycznie dokonane wybory, i to w odniesieniu do ściśle określonego materiału. Jednocześnie miały one mieć charakter refleksji metodologicznej, uzupełniać wyniki szczegółowe (publikowane często $\mathrm{w}$ wielu tomach i w różnym czasie) o spojrzenie generalizujące, nazywające w sposób bardziej uniwersalny to, co przez lata było chlebem powszednim badacza. Nie było więc miejsca na rozważania czysto teoretyczne, na wskazywanie możliwych przyszłych kierunków rozwoju kartografii historycznej, ani na szczegółowe opisywanie dokonywanej rekonstrukcji przeszłości. Spotkanie miało charakter przede wszystkim warsztatowy.

Zamierzenia te zostały po części zmodyfikowane w toku przygotowania sympozjum, w trakcie obrad i podczas opracowywania materiałów do druku. Winfried Schich i Joachim Stephan przyjęli zaproszenie jeszcze przed ostatecznym sprecyzowaniem problematyki, gdy spotkanie miało dotyczyć ogólnie kartografii historycznej; wtedy też przedstawili zarys referatu. Zgłoszony temat nie w pełni udało się wkomponować w nową formułę. Został jednak zbudowany wokół zagadnienia funkcji mapy na etapie analizy danych i prezentacji wyników, dzięki czemu stanowi cenne uzupełnienie tytułowej tematyki.

Pozostałe wystąpienia były zamówione i miały się odnosić do podstawowych zagadnień kartografii historycznej: rekonstrukcji warunków naturalnych (Alfred Kaniecki), sieci osadniczej (Marek Słoń), granic terytorialnych (Bogumił Szady - na przykładzie struktur kościelnych), przestrzeni miejskiej (Zofia Maciakowska). W programie sympozjum nosiły one ogólne tytuły, odwołujące się do całych dziedzin, choć nie mogły oczywiście referować w sposób wyczerpujący tak ogólnych zagadnień. Sieć osadnicza została omówiona na przykładzie prac nad serią „Atlas historyczny Polski. Mapy szczegółowe XVI wieku"; w referacie ograniczono więc do minimum konkretne przykłady, łatwe do odnalezienia w tej publikacji. Natomiast struktury kościelne i topografia miejska były prezentowane w odniesieniu do projektów przygotowywanych dopiero do edycji "Atlasu wyznań i religii w Rzeczypospolitej w XVIII w." i gdańskiego zeszytu „Atlasu historycznego miast polskich”. W tej sytuacji konieczne było przywołanie materiału szczegółowego. Z kolei wystąpienie Alfreda Kanieckiego było nie tyle nową próbą zebrania podstawowych zasad rekonstrukcji kartograficznej warunków naturalnych, co ich powtórzeniem. Był to cenny wkład w spotkanie warsztatowe, wręcz niezbędny w tak pomyślanej koncepcji obrad; nie było jednak sensu ponownego drukowania tez przedstawionych już przez autora we wcześniejszych publikacjach.

W nadziei, że zebrane tu rozważania okażą się przydatne dla badaczy podejmujących zadania z zakresu kartografii historycznej, oddajemy je w ręce Czytelnika.

Marek Słoń 